\author{
ロシアにおける中国人理解 \\ —メタファーとしてのディアスポラー \\ 堀 江 典 生 \\ (富山大学極東地域研究センター教授)
}

\title{
Chinese "Diaspora" in Russia as a Metaphor
}

\author{
HorIE, Norio \\ Professor, Center for Far Eastern Studies, University of Toyama
}

\begin{abstract}
This paper investigates "Chinese diaspora," the term used by the Russian media and in Russian scholarly articles to describe the Chinese residing and working in Russia either permanently or temporarily.

Although Russia's perceived threat of Chinese migration to Russia has calmed as compared to the 1990s, Russian citizens are still intolerant of Chinese inclusion into Russian society and the apparent unwillingness of the Chinese to adapt. Hostility against the Chinese can be avoided by understanding their activity in Russia, as well as the roots of Russian society's stereotyping of the Chinese. This paper focuses on the term Chinese diaspora because it has not previously been theoretically considered. In addition, whether this Chinese presence in Russia qualifies as actual diaspora has not been thoroughly examined, despite its wide use to describe the Chinese currently residing and working in Russia.

The aim of this paper is to examine how the term Chinese diaspora as a metaphor operates in Russian society, as well as how the boundary between Russian citizens and the Chinese has been maintained not by diasporic motivation, but by Russian motivation to perpetuate it.

This paper first examines how the term Chinese diaspora is used by the Russian media and in Russian scholarly articles, and then describes how this usage differs from the definition of diaspora in the theoretical sense and from how the Oversea Chinese worldwide define themselves as diaspora. This paper also examines the diasporic ties between Chinese migrants and their home countries and diasporic practices from a historical perspective. Chinese diaspora should be analyzed by the diasporic stances, projects, claims, idioms, practices, and so on, that are motivated from the diaspora side, even if they passively accept or adapt their diasporic stances. This analysis finds that there is no diasporic cohesion between new and old Chinese immigrants to Russia in term of their origins, and no consistent and well-organized diasporic practice.
\end{abstract}

Keywords: Chinese, diaspora, boundary, groupism, Russia 
This paper's investigation makes it clear that the Chinese diaspora in Russia does not presently exist from the perspective of diasporic theory and social practices. The term Chinese diaspora is a metaphor designed by Russia to maintain the boundary between Russian society and Chinese migrants.

The grouping of Russia's Chinese population into this putative diaspora keeps them arbitrarily bounded by the host society. With this grouping, biased views against Chinese immigrants remains as a device to instigate new threats against them or inflate existing threats, even if those who speak about the Chinese immigrants welcome them or not. The term Chinese diaspora in the Russian context should be used carefully. Its use hinders the Chinese by stereotyping them as a putative diaspora, provoking an inexplicable disquiet among the host citizens that keeps them intolerant of Chinese immigrants.

\section{は じめに}

1930 年代後半，旧ソ連極東地域から中国人抢よび朝鮮人住民の多くが強制的に国外追放と なり，中ロ国境では人の往来は厳しく管理されるようになった。それから1988年まで事実上 ロシアと中国の間には国境を往来する環境はなかった。1986 年のゴルバチョフ書記長の「ウ ラジオストク演説」は，急速に中ソ関係を改善させ，1988 年から中国人のロシアへの渡航が 再開されたが，続くソ連崩壊はロシアの国力の低下，中央の地方統治力低下を招き，中国と国 境を接するロシア極東地域に打いて安全保障への関心を高めることになった。安全保障のジレ ンマとしてアレクセーエフが描いたものは，中ロ経済交流が進み中国製品により恒常的な物不 足が解消される一方，それと表裏一体の中国人移民の流入打よびその経済力や文化の浸透が口 シア極東地域に颃いてロシアの主権を劦かすことになるのではないかとの認識を生み出すジレ ンマであり，それに伴らロシア市民の中国人に対する反移民的敵意の増殖であった（Alexseev 2006）。脅威を褟る議論と距離を扢こうとするならば，中国人移民脅威論が再燃しやすい環境 のしくみを冷静に分析し，敵意の増殖が連鎖することを防ぐ必要がある。

本稿では，ロシアの日常生活にあふ狄る様々なロシアの中国执よび中国人認識のなかで，「中 国人ディアスポラ」といら表現に着目し，それがどのようなメタファーとしてロシアに拈ける 中国人脅威論を支えているかを論じる。本稿は，ロシアが中国人の活動をどのように認識し， ロシアの住民や識者やマスコミが中国人をどのように集団として捉えようとしてきたか，換言 すれば，ステレオタイプがぞのように形成されてきたかを理解する試みである。ロシアのマス コミや一部研究者は，一時滞在者を含め中国人を「中国人ディアスポラ」と名付けて描くこと がしばしばある。ロシアの住民や識者やマスコミが中国人移民を大括りで異質な他者として描 き，他者を受け入れない境界を意図的に引くために利用される「中国人ディアスポラ」といら メタファーを考察することで，日常の言説のなかでみられるホスト社会の意図された「境界維 持」を批判的に検討したい。

\section{1 メタファーとしての中国人ディアスポラ}

ロシアにいる中国人をロシアでは「中国人ディアスポラ」と呼ぶ傾向がある。この傾向は， マスコミから研究者レベルまで広く見られる傾向である。ウラジオストクにあるロシア科学ア 
カデミー極東支部極東諸民族歴史・考古学・民族学研究所のビクトル・ラーリンは次のように 述べている。

「近年, 中国人労働ディアスポラがロシア東部国境地域に和いて安定的な基盤を形成してい る。それは契約労働者と企業・合弁会社の雇用者, 零細企業家, 主にビザなし観光の資格で ロシアに訪れる商人などによって構成されている。」(Ларин 2001, 96-97)

この「中国人労㗢ディアスポラ」といら表現は，ラーリンが定住者に限らずに援用している ことから，中国人労働移民といら程度の用法で使ったのだろらと思われる。ロシアのマスコミ に怙いてもとらであるが，出稼ぎ労働者も含め，短期滞在の中国人に対してもディアスポラを 移民という言葉と同義で使う場合が散見される。

ロシアにとって異質な民族集団としての中国人の存在に対して，ディアスポラといら言葉が 流布する傾向にあると考えられる。ロシアの新聞各紙を検索すれば，かならずどこの新聞でも 中国人ディアスポラといら表現を見いだすことができる。具体例を挙げてみよう。

「モスクワで最も閉鎖的な集団のひとつである中国人ディアスポラの生活がどのようなもの であるか，明らかになった。」(1)

これは，モスクワ大学のヴィリャ・ゲリブラスの研究を紹介しながらチェルキゾフスキー市 場での中国人移民の活動や中国人労働者，商人，中国人留学生の現状を記事にしたものである。 この記事には，この「中国人ディアスポラ」といら表現の他に「中国人」，「中国人移民」，「中 国人商人」,「中国人学生」,「中国人院生」といった中国人を表す言葉とともに，「中国人共同 体 (китайская община)」といら集団性をもつ名称も使われている。この記事で紹介されたゲ リブラスの優れた論文（Гельбрас 2009）には，「中国人ディアスポラ」といら表現も「中国人 共同体」といら表現も出てこないにもかかわらずである。

「人権運動家やジャーナリストによれば，ウラル南部の農園に拈ける中国人の労働は，ふた りの中国人によって管理されており, 彼らはトリアドと呼ばれる犯罪組織の代表である。そ のらちの一人は, チェリャビンスクの高級ホテルに住んでいて, 月 30 万ルーブルの家賃を 払っている。スズダロヴァによれば, この中国人ディアスポラの代表たちは, 野菜の販売で 儲けたルーブルを毎月ドルに換金し，税金を払うことなく本国に送金している。」 ${ }^{(2)}$

この記事も，定住者や非定住者の区別なく，中国人ディアスポラといら表現を利用している のがわかる。これらの例は，特に中国人移民問題をことさら大げさに報道することを目的とし た著者や記者だけによるものではない。ロシアの学術界でもマスコミでも，「中国人ディアス ポラ」を，本来の意味での移民であろらが，移民に分類されない一時滞在者であろらが，口シ アにいる中国人を総称する意味で使われることが多い。

(1) Известия, http://www.izvestia.ru/news/349576 (retrieved on 28 June 2010).

(2) Независимая, http://www.ng.ru/regions/2011-09-20/5_slaves.html (retrieved on 29 March 2012). 
もちろん，ロシアの移民研究者のなかには，一般に流布する中国人ディアスポラといら言説 を戒めるために，中国人ディアスポラという見方はロシアに拈いて成立しないと諭す研究者も いる。ザグレブノフ (Загребнов 2007）は，ロシア極東地域の中国人が国境沿いの教育レベル の低い二時滞在者であることから, ディアスポラと呼ぶことに反対している。ちなみに, 本来, 教育レベルはディアスポラ概念の重要な要素ではない。

ゲリブラスも安易にディアスポラといら言葉を中国人集団に当てはめるべきではないとして いる。彼は, ロシア語で移民集団を表す言葉でディアスポラ，共同体（община）, 同郷人組織 (землячества）を区別し，中国人移民の分析視角として「同郷人組織」を採用している (Гельбрас 2001; 2004, ゲリブラス 2005)。ディアスポラ, 共同体, 同郷人組織は, ロシア語 ではしばしば類語・同義語として扱われてきただけに，ゲリブラスはこの 3 つの峻別により中 国人移民分析に新たな境地を見いだした。

ロシア科学アカデミー極東研究所のアレクサンドル・ラーリンは, 中国人コミュニティを通 じてディアスポラ的活動を事実上行う「疑似ディアスポラ（квазидиаспора）」として描いて いる。彼は, 現代の中国人移民は, 安定的でよく組織化されたエスニック集団ではなく，常に メンバーを変える短期滞在型の中国人移民の間でディアスポラとして民族文化の統一性を共有 することはできないが，集団的活動を支えるコミュニティ組織と活動があり，「疑似ディアス ポラ」としての特徴を表している，と主張する（Ларин 2009, 156-159）。この本には，そらし たコミュニティ組織が多く挙げられているが，それらの組織がどのよらな活動を行っているか は言及もなく，ディアスポラ的活動を行っているかどらかが分からないままである。彼は，中 国人脅威論を疜らない良心的なロシアの中国研究者であるが, そうした論調のなかにも, 中国 人を擬似的であれ，ディアスポラとして集団化させ理解しょうとする傾向がロシアにある。

中国人を移民であれ一時滞在者であれ，総じてディアスポラと呼ぶ傾向は，ロシアだけなの だろらか。どのようにロシアに拈ける「中国人ディアスポラ」といら表現は特異なのだららか。 「中国人ディアスポラ」といら表現の根源と広がり，そしてロシアの中国人がディアスポラた りえるのかを判断する分析視角を移民研究のなかに探っていこう。

\section{2 移民研究における「中国人ディアスポラ」という表現}

中国人ディアスポラといらイディオムはそもともロシアだけでなく, 世界的に誇張される傾 向にある。ただし，ディアスポラが，「あまりに深いユダヤ人的刻印が刻まれている」(臼杵 2009, 21）がゆえに，その概念拡張に異議を捉えようとするのが本論の目的ではないし，本当 の意味での「ディアスポラ」とは何かを問拈らとしているわけではないことは最初に断って拉 きたい。「ディアスポラ」といらメタファーが, ホスト国に招いて誰によってどのよらな装置 として機能するかが, 本論にとっての最大の関心事である。ホスト国がどのように在外中国人 およびその一部を名付故か，在外中国人のなかで中国人ディアスポラはどのよらに定義され ているのかをまず見てみよう。

シンガポールのチャイニーズ・ヘリテージ・センターが発行する『華人エンサイクロペディ ア』では, 華人 (Chinese Overseas もしくは Overseas Chinese) は単に中国本土に住む中国人以 外を指すのではなく, 本土中国人, 香港や台湾の中国人, 海外留学生, 海外に一時的に在留し ている中国人，そして完全にホスト国で同化した中国人を除いた中国人で，ホスト国で定住し， 
帰化した中国人を指す。この華人といら言葉は，よく中国人ディアスポラと同義的に使われる が，このエンサィクロペディアでは，ディアスポラはよいイメージと捉えて拈らず（Pan 1998，16）， あえて華人といら言葉を利用している。チャイニーズ・ヘリテージ・センターは, 世界に散らばる中国人コミュニティをグローバルに総体として研究するために 1995 年に設立 され，このエンサイクロペディアは華人自らをどのように定義しようとしているかを考劣るら えで，興味深い。世界に分散する中国人コミュニティを総体として描く言葉として「華人 (Overseas Chinese)」を定着させたのは，このエンサイクロペディアの編者のリン・パンであ るとされ，この「華人 (Overseas Chinese)」が中国人ディアスポラと同義として使われるよう になってきた (Ang 2006, 324)。このことは, 華僑・華人研究とディアスポラ研究との架橋に は賛否両論はあるものの（陳 2009, 31-32），華人自身が定義し，少なくとも広く普及するょう になった中国人ディアスポラの定義の原点は華人にあることを示している。つまり, 中国人ディ アスポラにとって中国人ディアスポラであるための条件のひとつは，ホスト国で定住し，帰化 した中国人でなければならない(3)。

ディアスポラの定義は様々である。ここでは, ブルーベイカーがまとめた包括的なディアス ポラの特徵をとりあげょう。ブルーベイカーは, 従来のディアスポラ概念を形成する中心的な 基準として，3つの基準，(1)離散（Dispersion），(2)故郷志向（Homeland Orientation）そして， (3)境界維持 (Boundary-Maintenance) を挙げている (Brubaker 2005)。離散は, もっとも広くディ アスポラを定義する場合に使いやすい基準であり，空間的に離散する者はすべてディアスポラ の成員であるとする無限のディアスポラ定義の拡張に寄与する。ただし, 離散は, 単なる空間 的な拡散ではない。少なくともディアスポラ論では,「強制された離散ないしはトラウマ的な 離散」との認識が, コーエン（Cohen 2008）にも見られるよらに，広く一般に受け入れられて いる特徵である。第二基準である故郷志向は，想像上もしくは実際の郷土への志向であるが， ディアスポラたることを権威づける価值・アィデンティティ・忠誠心の源泉となる。とはいえ, ディアスポラにとっては，故郷志向が重視されず，在留地の水平方向の絆にこと意味があると するディアスポラの脱中心化の議論もある。第三基準である境界維持は, ホスト社会とは明確 に区別できるアィデンティティを維持し続けることを意味し，自ら意図的に同化に抵抗するこ とで境界は維持される。

全ての移民がディアスポラを形成するわけではない。エスマンによれば，移民と「ホスト国 との間の, そして, 彼らと他のディアスポラとの間の境界を生み出す独自のコミュニティを形 成する者たちだけがディアスポラを形成する」のであり，「こうした境界は，ホスト国に扣い て自らの独自のアィデンティティや特有の文化を維持しようとする移民達によって生久出され るもの」(Esman 2009, 14-15) である。エスマンのディアスポラの定義は, コーエンらのディ アスポラ定義よりも柔軟であり,より日常的に利用されている意味に近いし, 特に古典的なディ アスポラ概念からの脱却を試みている点で興味深い。広く設定したエスマンのディアスポラ概 念に抢いても，移民側によって引かれる移民とホスト国社会との間の境界とその維持が，ディ

(3) 華人によるディアスポラの自己定義は重要であるが，筆者は華僑のディアスポラ的実践を無視しない。 それゆえ，本稿では華人でないことをロシアの「中国人ディアスポラ」をディアスポラでないとする 根拠にするつもりはない。筆者は, 後述の分析を見てわかるように, こうしたディアスポラ定義よりも, ディアスポラ的実践による境界維持を，ディアスポラがディアスポラであるための条件であると考觉 ている。 
アスポラの認知にとって重要な要素である。

さらに，ディアスポラは，境界をもつ実体といらょりは，「イディオム (Idiom)」,「立ち位 置（stance）」や「主張（claim）」を通した社会的実践（social practice）と考えるべきであると ブルーベイカーは論じている（Brubaker 2005, 12)。すでに述べたように，境界は同化への意 図的な抵抗により維持される。ホスト国・社会側による移民の社会的排除の結果であろらと， 移民側の社会的実践として, はじめてディアスポラとしての境界は維持される。もしロシアに 扣ける中国人の「イディオム」,「立ち位置」，「主張」が母国とのつながりを維持し，境界維持 のための実践がなされているならば，それは中国人自身が自らをディアスポラとして集団性を もち, ディアスポラとしての境界を見いだし，維持しようとしつづけていると理解することが できよう。ブルーベィカーがこれらの概念を通じてディアスポラ概念の脱実体化を試みたのは, 結局，ディアスポラとは，アィデンティティ形成のある種のプロセスであり，その実践だから である。ディアスポラ的実践のない移民集団をディアスポラとして実体化しているかのように 捉えるのは，ホスト国市民の恣意的境界維持行為である。

次節では，ディアスポラ概念を構成する境界維持の実践に着目して「中国人ディアスポラ」 を考察し，中国人側のディアスポラ的実践によりどのよらに境界が移民側から維持されている か，もしくはホスト国側から染意的に境界維持がなされているかを検討してみたい。結論を先 取りするならば，ロシアに拈ける中国人ディアスポラとは，中国人自身のディアスポラ的実践 をもとに中国人が形成してきた境界といらょりは，少なくとも彼らの「実践」とは関わりなく ホスト国側が想像した中国人ディアスポラとしての「立ち位置」と「要求」, もしくはホスト 側の「立ち位置」と「要求」によりホスト国側が自ら設定した境界である ${ }^{(4)}$ 。

\section{3 ロシアの中国人は「中国人ディアスポラ」たりえるか？}

ロシアの中国人がディアスポラたりえるかを考光るめほは，まず「中国人ディアスポラ」， あるいは，そのように想像・想定される集団が，どのようなディアスポラ的実践を行っている かを考光，もし，ディアスポラによる境界維持の実践が薄弱であるならば，「中国人ディアス ポラ」なるものを脱実体化することができる。前節で論じたディアスポラの定義とディアスポ ラを実体化させる社会的実践の観点からすれば，故郷志向を示すものはディアスポラの紏と出 自であり，ディアスポラの社会的実践のなかにディアスポラ側から引かれる境界の維持のあり 方が見えてくるはずである。本節では，ディアスポラとしての絆とディアスポラ的実践に分け て，ロシアの中国人を考察してみよら。

\section{(1) ディアスポラとしての絆}

Cohen によれば，ディアスポラがディアスポラたるゆえんは，過去の移民の歴史との分かち がたい絆と同じバックグラウンドを分かち合ら人々との共通の民族性を受け入れるところにあ る(Cohen 1997, ix)。ディアスポラ形成にとって, 歴史的な根源と絆ことが現在のアイデンティ

(4) ディアスポラと呼ばれながら, 同様にディアスポラらしい「立ち位置」や「要求」が見られないグルー プとして, 米国のアルメニア人が挙げられる。アルメニア人たちは, 自らディアスポラ的「立ち位置」 から逃机ようとし, 母国や他国のアルメニア人とのつながりから距離を置こうとする (Brubaker 2005, 12)。 
ティと所属を決定するらえで重要である。これはディアスポラ概念に拈いて広く共有されてい る原則である（Toninato 2009, 3)。移民は，ホスト国に拈いてディアスポラを形成することは できるが，ホスト国に滞在することで自動的にディアスポラが形成されるわけではない。こう した世代を重悋た，もしくは世代を超えた歴史性は，ディアスポラ形成の重要な要素である。

1980 年代後半からの中国人出稼ぎ労働者が，原初的ディアスポラとしてディアスポラ・コ ミュニティを形成してきたと論じることはできるだろらか。多くの研究が示すょらに，現在の ロシアの中国人の多くは，一時滞在者（sojourner）である。ゲリブラスは，自らの社会調査て 世帯主の $1.4 \%$ だけしか妻をロシアに連れて来ることを望んで拈らず，子供を連れてくるとな るとさらに少ないと示している。都市に住む中国人の $57.3 \%$ は単身赴任であり，家族ととも にロシアにやってきた中国人は 2 割に満たなかった（17.9\%）という（Гельбрас 2001, 6667)。ロシアで国籍取得を希望する中国人は，一割強（12.5\%）しかいない（Гельбрас 2004, 90)。また，ラーリンは，2000 年代初め，ロシア極東地域でロシア国籍を取得するか，一時も しくは長期の居住許可を取得した中国人は 1000 人に満たないと論じている(Ларин 2006, 393)。ロシア極東地域で働くほとんどの中国人は, ロシアの滞在を一時的なものと見なしてい る（Repnikova and Balzer 2009, 13）。家族も中国に残し，単身で訪れ，国籍も居住許可も必要 としないロシアの中国人は，その意味では，華人ではなく華僑的活動を行う中国人である。

現在ロシアに在留する中国人が，華人でなくとも，また，十分な歴史性がなくとも，世代を 超えて, つまり帝政期からのロシアに残る中国人との連携のなかに, ディアスポラ社会が形成 されることはあり得るだろう。しかし, 旧ソ連時代にロシアに帰化した初期の中国人（オール ド・カマー）の存在が非常に脆弱である。中国人は, 1930 年代半ばに民族浄化の対象となっ た少数民族のらちのひとつであった。多くの中国人（一時滞在者であれ，帰化者であれ）が, このとき母国へ送還されるか，肃清の対象となった。本国に送還された者の運命は，1966年 から 76 年まで続く中国文化大革命の犠牲であった（Benton 2007, 27）。肃清の嵐の後の 1959 年のソ連邦センサスでは, 中国人は 19097 人，そのらち中国語を母国語とした者は $75.1 \%$ の 14343 人, ロシア語を母国語とする者は $24.2 \%$ の 4631 人いた。 2002 年ロシア連邦センサスでは, 中国人は 34577 人で，そのらち中国国籍をもつ者は 30598 人，つまりロシア国籍の中国人は 3979 人と非常に少ない。対象となる領土が異なる両センサスの比較は意味がないにせよ，口 シアではオールド・カマーは極端なマイノリティであった。

中国からの移民は, 非常に地方特化した出身地から特定の移動先への移民によって構成され て和り，そのことは「中国人ディアスポラ」という大風呂敷の概念とはそぐわない（Skeldon 2003, 59)。それゆえ， ロシアのオールド・カマーとニュー・カマーはどこからやってきて，同 じ老郷ゆえのディアスポラ的結合があるのかどらかを検討することは，口シアに拉ける中国人 ディアスポラの実体化・脱実体化にとっては，重要である。

帝政ロシアへの中国人出稼ぎ労働者の主な供給源は，山東省であることは不思議ではない。 これは，現在の山東省煙台市が対口交通網の拠点であり，ロシア革命前後のロシア極東地域の 中国人商人の主体は，山東商人であったためである。1917 年のハバロフスクの中国人商店 121 軒のらち 116 軒 $(96 \%)$ が山東商人によるものであったし, 中国東北地方の黒河で活躍する商 人の多数派は山東商人であった（徐 1999）。また，山東省のなかでも登州府，莱州府，青州府 など東部の山東半島地域からの出身者がシベリア・極東地域に多く分布していたという（荒武 2008)。 
当時, ロシア極東地域への中国からの出稼ぎに必要な旅券申請は, 芝罧で行われており，そ の斡旋に芝罧の宿所経営者が係わっていた（サヴェリェフ 2005, 229）。ハバロフスク市の中国 人移民の $95 \%$ ，ニコリスク市の $88 \%$ ，ウラジオストク市の $75 \%$ が山東省出身であったという。 中国人契約労㗢者の募集は山東省にて行われ，山東省煙台の港とともに山東省や華北とロシア 極東地域をつなぐ交通機関が整備されていたことより，山東省はロシアに中国人移民を送り出 寸役割を担っていた（サヴェリェフ 2009, 45-46)。Boyko も，1920 年代の西シベリアの中国人 の出自は多様であったが, 山東省, 特に煙台出身の者が多かったとしている（Boyko 2001, 20)。また，山東は移民の出自としては多数派を占めるために，山東以外の出自の移民たちも 自らを山東人と自称・詐称するケースもあり,「山東老郷」は満州地域に広がる一種の「移民 伝説」となっていたという（荒武 2008, 276-279）。満州, シベリア, ロシア極東に括いて, 当時, 山東は「ブランド化」していることも勘定に入れて扔く必要がある。

現在，ロシアにいる中国人の出身地は，オールド・カマーの出身地とは大きく異なる。2002 年にゲリブラスが行った社会学的調査では, イルクーツクでは中国東北 3 省 (黒龍江省, 遼寧 省，吉林省）の出身者が $52.9 \%$ ，八バロフスクでは $90.1 \%$, ウラジオストクでは $52.6 \%$ を占 めるという（Гельбрас 2004, 85）。特に, ロシア極東地域では, 黒龍江省出身者が目立った存 在である。

帝政ロシア時代, 北京条約によって定められた国境の両岸は, 定住者の少ない地域であった ため, 欧露部からの入植者と中国人の北上とがぶつかり合う地点であった。中国東北三省の人 口拡大は, 口シア人の南下を懸念した清国政府の積極的定住策と相まって, 山東省出身者を中 心とする漢人移住者の定住化によって実現されていたし（サヴェリェフ 2005, 208），その国内 移住の延長線上にロシア極東開発の労働力需要があった。とはい光, 帝政時代の中国人が山東 省出身であることと，現代ロシアで働く中国人が山東省由来をもつ黒龍江省出身者であること を関連づけて，同じ僑郷をもつ者たちの社会的ネットワークがあると見なすには無理がある。 老華僑（華人）と僑郷との社会的ネットワークの維持なしに, 老華僑（華人）と新華僑（華人） の受入国に打ける社会的ネットワークの発動を当然と見なすことはできない。それゆえ，ロシ ア極東に打いて, オールド・カマーとニュー・カマーのディアスポラ的結合は, 自明とはいえ ない。

中国人ディアスポラに関しては，受入国に扣けるディアスポラ形成において，いきなり集団 的想像力たる中国なるものが華人達をつなぐわけではない。同じ老郷という共通の出自と老郷 との社会的関係維持なしには，中国人ディアスポラの実体化は難しい。ロシアにオールド・カ マーがやってきた頃の山東出身者は，世界の移民システムに大きく関わってきた華人達であっ たが，中国東北地方，特に，黒龍江省出身者は，そらした世界の移民システムに参加するょう になったのは最近のことであり, その向から先もロシアが中心のマージナルな存在である。そ れゆえ, オールド・カマーとニュー・カマーの出自の違いとディアスポラ的結合の不在は, 中 国人ディアスポラ形成を疑らひとつの要因となる。

\section{(2) ディアスポラ的実践}

境界維持を，その社会的実践において中国人ディアスポラに見いだそうとするのなら，ディ アスポラ活動を支える社会組織の実践に着目する必要がある。

帝政末期からソ連までのロシアの中国人は，ディアスポラとしての境界を維持できなかった 
だけでなく, 存在そのものも維持できなかった。サヴェリェフは, ロシア極東への帝政時代の 中国人・朝鮮人・日本人移民を定着パターン，同化・帰化過程の特徵，規模などによってタィ プ分けしたところ，中国人移民は非熟練労働者と商人が支配的な多元的移民であるとしている （サヴェリエフ 2005, 287）。そうした山東省出身の中国人移民（一時滞在者も含め）が，ホス 卜社会から孤立し，母国の伝統文化を保持し，同郷の人間関係を維持し，ロシア国内でエスニッ ク・ネットワークを保ったと考えている。中国人街（中国人集落）が各都市に形成され，1890 年代には「百万人街（ミリオンカ）」と呼ばれるようになっていたという（サヴェリェフ 2005, 224)。帝政時代，1889年に「清国人自治団」がロシア政府の要請に基づき設立された。中国 人移民の管理，徵税，住民登録の徹底を行らためのものであったが，「極めて限定的な組織化」 （サヴェリェフ 2005, 139）であったという。この自治団は, 1898 年に強制的に解散させられる。 中国人社会の隠密行動の温床とロシア政府が判断したからである（Ларин 2009, 55）。

1920 年代の中国人コミュニティは, 難しい立場にあった。ソ連時代の華人組織は, モスク ワ中山大学 (孫逸仙大学) 同様に短命に終わっている。中国の利益となるように非合法的活動 を行う危険性があるとして，1923～1924 年に華人組織メンバー逮捕とともに, 古くからの華 人組織そのものが閉鎖された（Ларин 2009,127）。1920 年代末にも中国人は肃清の対象となっ た。華人労働者同盟なども 1920 年代末に消隇している。1920 年代後半, 中国人の本国強制送 還や逮捕などが広範に行われるよらになると，華僑の帰化が増加したが，1930 年代にシベリ アで設立された華人共同体組織の多くも長続きはしなかった（Boyko 2001, 24）。ボイコは, 「西 シベリアの中国人コミュニティは, 故郷からも, ロシアの定住先でも, 極度に離散させられた」 存在であるとし，旧ソ連時代の中国人は「人口社会学的構成としても文化的構成としてもロシ アの民族地図から実質的に消滅」しているがゆえに，「西シベリアの中国人ディアスポラは, 東アジアや米国やその他の国々の中国人ディアスポラとは著しく異なる」としている（Boyko 2001, 24-25)。

第二次世界大戦期には, シベリアや極東地域の市場には中国人が野菜を売る姿が見られたが, 第二次世界大戦後はその姿も見られなくなった。ソ連崩壊後に中央アジアに強制的に移住させ られた朝鮮人がロシア極東地域に帰還したが，国外追放の目にあった中国人がロシア極東地域 に戻ってくることはなかった（Pal 2007, 45）。それゆえ，1990 年代初期，シベリアやロシア極 東地域の人々にとって，中国人の出現は，「ただ予期せぬ出来事であるだけでなく，まったく 新しい出来事」（デャトロフ 2010, 288）であった。ロシア人にとって, 旧ソ連時代の長い期間, 中国人問題はなきに等しい問題だった。

19 世紀から 20 世紀初頭までの中国人ディアスポラと現代ロシアの中国人との間には, 歴史的 連続性も世代を超えた連携も存在しない。マスロフは, 1950年代にロシアにやってきたオール ド・カマーと 90 年代のニュー・カマーの間には明確な線引きがあり,「モスクワ在外華人協会」 がその2世代の関係を仲介する役目を担っていると考えられていると論じている (Maslov 1998, 331)。しかし，マスロフの挙げた中国人ディアスポラ組織が現在も存在するのかぞらか，確認 はできなかった。中国企業家連盟 (Лига китайских предпринимателей) は, 中国人ディアスポ ラ組織とされ，スベルドロフスク州の中国人の課税・関税問題のコンサルタント業務や支援を 行うといら報道は, 中国人同郷人組織の活動の一端として報道で伝えられている ${ }^{(5)}$ 。露中通商・

(5) Новый Регион 2, http://www.nr2.ru/ekb/13_44600.html (retrieved on 11 May 2011). 
経済友好センター (Российско-Китайский Центр торгово-экономического сотрудничества) もまた, 中国人ディアスポラ組織として紹介されるが, 1998 年に設立されたこの組織は, 実際 のところは，ロシア産業企業家同盟のイニシアティブによるものであり，ディアスポラ組織と は言えない。少なくとも，これらは露中貿易や投資プロジェクトの円滑な促進を両国政府の支 援のもとに行らことができるように設置された組織であり，在露中国人とホスト国市民との間 の境界を維持しょうとするディアスポラ行動に関連する組織ではない。これ以外に，大小様々 な華人組織があっても扮かしくないが，ゴンチャロフによれば，ロシアの華人組織は十分に機 能して抢らず，モスクワの中国人の役には立っていないという（Goncharov 2003，39）。少なく とも, いまのところロシアで働く短期滞在中国人やロシアに移住した長期滞在・帰化中国人の 間に商工会的活動以上の動きは見られず, 顕在化したディアスポラ活動は見られない。「人民網」 ロシア版では，モスクワ中国平和的統一促進協会やモスクワ商工会の代表が中国人ディアスポ ラを代表するかのようにウイグル問題やチベット問題について発言した記事などが掲載される こともあるが ${ }^{(6)}$, この協会の活動をロシア側メディアが同様に報道しているわけではない。そ して，そこで語られている「中国人ディアスポラ」の声は，少なくともロシアの華人のイディ オムでもなければ，出稼ぎ労働者のイディオムでもない。

また，ビクトル・ラーリンによれば，ロシア極東にはチャイナ・タウンは未だ存在せず，口 シア極東に現存する中国人コミュニティも，多くの中国人を引きつける存在として機能を果た していなし，こうしたコミュニティの数は微々たるものであり，中国人の間での影響は限られ たものであると論じている（ラーリン2006,75）。また，ラーリンは，ハバロフスクやウラジ オストクなどに設立された中国人の社会組織を取り上げて，中国人の団結を図る意図があると 述べる一方で, 現地中国人留学生がまったくそれらの活動を把握していない事実を示している。

デャトロフは，ロシアの都市の中国人市場が，ディアスポラ化を支劣る社会的組織になって いると論じている。イルクーツクの中国人市場「上海」を例に，こうした市場が単なる市場か ら中国人商人のロビー活動などを行ら社会組織へと進化する姿を描き，中国人のディアスポラ 化の可能性を論じている（Дятлов 2005, 104）。中国人市場が中国人移民組織の母体となって ディアスポラ活動を支光るとする発想であるが，デァトロフが描いたその中国人市場はすでに 消滅している。

ロシアで働く一時滞在型中国人が，あたかも世界に展開する中国人ディアスポラの一部のよ らに描き，ロシア極東地域社会への脅威となる中国人移民の到来を描く概念として便利に利用 される「中国人ディアスポラ」という概念は，現実との距離があるばかりでなく，䛊ったステ レオタイプを植え付ける道具となる。ロシアの移民研究者のエキセントリックなこの概念の活 用と迂闊なマスメディアによるこの言葉の乱用は, 顔の見えない中国人の異質性をさらに警戒 すべきものとしてロシア移民社会を語る文脈に保存する。

\section{4 ホスト社会の恣意的な境界維持}

中国人ディアスポラといら表現は，ロシアに拉ける中国人認識を漠然としたディアスポラと

(6) ウイグル問題については, 民網ロシア版, http://russian.people.com.cn/31519/6697452.html（retrieved on 19 September 2013), チベット問題への発言については, 人民網ロシア版, http://russian.people. com.cn/31521/6379996.html（retrieved on 19 September 2013）を参照されたい。 
いら範疇に入れ込み，中国人ディアスポラを総体としての中国人に対する呼称とし，緊張を解 かないメタファーとしてしまっている。むろん，ロシアには，ロシア人以外の異民族外国人を 中国人に限らずディアスポラと表現する傾向はある。ただし，それが脅威の対象とされるとき， ディアスポラを実体化しょうとする受入国側の政治的動機と結びつきやすい。それゆえ，これ はあまり賢明なメタファーではない。

現在のロシアに長期在留する中国人は少ない。ロシアに扎いて中国人として目立つ存在は, ロシアに居住許可をもっている一時居住者, 長期居住者, 定住者ではなく, 外国人労働者とし て登録されている一時滞在者である。これは, 多分に現在のロシアの移民政策によって強いら れた特徵であるといらことができる。帝政期括よびソ連期肃清までの中国人に長期居住者・定 住者がいたことはすでに述べたが, 現在でも制度が許せば長期滞在を望む中国人が多いことは, 近年の社会調査に拈いても明らかである。ただし，ロシア国籍を取得し帰化することを望む者 は，非常に少ない。

現在のロシアの移民政策は, CIS 諸国からの外国人労働者の受入を積極的に行い, 国籍取得 への道筋を描いているものの, 非 CIS 諸国からの外国人労働者の受入については障壁を高くし, 国籍取得までの道程は険しい（堀江 2010）。ロシアで働くには, 労働許可が必要であり, また, 労働許可割当といらキャップも設けられている。非 CIS 諸国からの外国人労働者は, ロシア 入国前に労働許可を取得しなければ, ビザそのものが発給されない。高度人材に関する労働許 可の規制緩和は 2007 年から行われたが, 中国人にとってロシアの移民政策は, 短期就労に限 定し，その後ただちに母国帰還を事実上義務づけるものであった。

ある調査では, ロシア極東地域住民の間では, 中国人不法移民と労働移民に対しては否定的 態度が優勢であるが, 旅行者, ビジネスマン, 商人に対する態度は肯定的態度が否定的態度を 上回っているという。同時に, ロシアとアジア太平洋地域諸国との関係に関する住民評価では, 現状以上に将来に対する中国との関係に米国や日本との関係以上に期待を示している構図が示 されている (Ларин 2006, 284-285)。ロシア極東地域での経済発展に積極的にアジアの外国人 労働力を活用すべきとして,「発展のための移民（受入）」を唱える研究者もいる（Безруков и Горбенкова 2006)。中国から労働力不足に悩むロシア極東やシベリアへの労務輸出は, 中ロ両 国にとって利益のあることであるとの積極的な評価もある（Гришанова 2009, 69）また，好む と好まざるに関わりなく, ロシア極東地域は, 中国東北地方や北朝鮮, ベトナムなどからの外 国人労働者を「効率的な労働資源」として活用せざるを得ない段階にきている（大津・アブデー エフ 2010, 156-157)。ロシア極東地域では，中国人移民問題や中国脅威論が再燃しやすい地域 であることは確かであるが, 現実的な選択として国境を通じた中口経済関係を肯定的にとらえ， 共存していく未来を住民自身が見据えているとする主張は, 近年の大きな研究潮流のひとつで あると考兄らる。1 18 世紀末のプリアムール総督府のアジア人移民政策は, 「アジア人移民を “統制しつつ利用する” 政策」（松里 2008, 309）であったとされるが，それは現代ロシアの中 国人出稼ぎ労働者に対してもよく当てはまる。

「中国人ディアスポラ」といら言葉は，ロシアに生じている新しい何かを説明するものだろ らか。同化しない異質性へのいらだち, 同化することに我慢できないいらだち，これらは中国 人がディアスポラ的要求として決然とホスト社会に対峙しょうとしたものではなく, 受入国側 の政治的・社会的ディスコースに活用された想像されたディアスポラである。ロシアに拈ける エスノフォビアは，ロシア人のアィデンティティの維持を目的としながら，自己を他の民族グ 
ループに篇しく対峙させることへと駆り立てる（オレフ 2010, 313）。「中国人ディアスポラ」 といら言説をそうした所作のひとつと考えるならば，この言説は，ホスト国がなんとしてでも 中国人をディアスポラ化させようとする装置になる。中国人ディアスポラといら言説は，少な くとも現在のロシアにいる中国人自らのイディオムではないし，それに反映されるディアスポ ラ的実践もない。

中国人をディアスポラとして実体化させる試みがロシアの移民研究者のなかで行われてき た。「中国人ディアスポラ」はロシアの移民研究者やマスコミに指名されて存在することになっ た「想像されたディアスポラ」である。「中国人ディアスポラ」の境界は，ロシアに在留する 中国人が意図的に維持を図った境界ではなく，ホスト国側が維持しようとする境界である。口 シアの中国人の活動を冷静に受け止める素地を作るには，中国人抢よびその移民理解は少なく とも「意図的な定義を通じて集団性に押しつけること」（Brubaker 2005, 13）であってはなら ない ${ }^{(7)}$ 。

\section{参 考 文 献}

荒武達朗 (2008), 『近代満州の開発と移民 : 渤海を渡った人びと』汲古書院。

臼杵陽 (2009), 「「方法としてのディアスポラ」の可能性」臼杵陽（監修）『ディアスポラから世界を読む: 離散を架橋するため』明石書店。

大津定美・Yu. アブデーエフ (2010), 「北東アジア国際労働力移動とロシア極東」大津定美・韓福相・横 田高明編著『北東アジアに拈ける経済連携の進展』日本評論社。

オレフ・グリゴリー (2010), 「ロシアに扔ける超エスノフォビア」堀江典生編著『現代中央アジア・ロシ ア移民論』ミネルヴァ書房。

サヴェリエフ・イゴリ（2009），「第一次世界大戦期の中国人移民：ハルビンに括けるロシア企業による契 約労働者の募集をめぐる諸問題」『国際開発研究フォーラム』38。

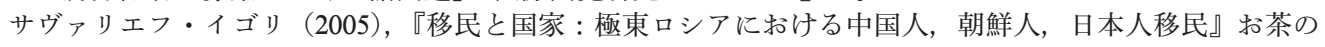
水書房。

デャトロフ・ビクトル (2010), 「シベリア・極東地域におけるステレオタイプと移民恐怖症」, 堀江典生 編著『現代中央アジア・ロシア移民論』ミネルヴァ書房。

ラーリン・ビクトル (2006),「ロシア極東の中国人：地域に抢ける見方」赤羽恒雄・アンナ・ワシリエバ 編『国境を越える人々: 北東アジアに打汄人口移動』国際書院。

ゲリブラス, ヴィリヤ (2005), 「ロシアに抢ける中国人の同郷人組織とマイグレーション」大津定美編『北 東アジアに打ける国際労働力移動と地域経済開発』ミネルヴァ書房。

徐万民（1999）,「ロシア極東に打ける中国山東商人」『環日本海研究年報』(新潟大学大学院現代社会文化 研究科環日本海研究室) 6 号。

陳天需 (2009), 「『Where is Home?』から『Home Everywhere』へ: 漂泊する華僑・華人たちのネットワー ク」庄司博史編『移民とともに変わる地域と国家』国立民族博物館。

堀江典生 (2010), 「ロシアの外国人労働者管理の課題 : 高度人材の受入をめぐって」大津定美・韓福相・ 横田高明編著『北東アジアに扔ける経済連携の進展』日本評論社。

松里公孝 (2008),「プリアムール総督府の導入とロシア極東の誕生」左近幸村編著『近代東北アジアの誕生: 跨境史への試み』北海道大学出版会。

Безруков, И.С. и Е.В. Горбенкова (2006), Переспективы использавания азиатской рабочей силь в экономике Дальнего Востока России, Влвдивлсток: ВГУЭС.

Дятлов, В. (2005), Миграции, мигранты, «новые диаспоры»: фактор стабильности и конфликта в регионе, пед. В. Дятлов, С. Панарин, М. Рожанский, Байкальская Сибирь: из чего складыввается стабильность, Иркутск: Ноталис.

Гельбрас, В.Г. (2001), Китайская реальность России, Москва: Муравей.

Гельбрас, В.Г. (2004), Россия в условиях глобальной китайской миграиии, Москва: Муравей.

(7) ロシアの中国人をひとつの集団として, 内的に同質で, 外的に境界をづけられ，共通の目的のために 統一的な行動をとる行為者ととら兄る傾向は, Brubaker(2002)が言うところのグルーピズム (groupism) であり，それによる脅威論はそらした傾向の問題多き帰結のひとつである。 
Гельбрас, В.Г. (2009), Китайские мигранты в Москве, Ж.А. Зайончковская, Н.В. Мкртчян, О.И. Вендина, Е.В. Тюрюканова, Т.Д. Иванова, В.Г. Гельбрас, Иммигрантыл в Москве, Москва: Три Кватрата.

Гришанова, А.Г. (2009), Иммигранты из КНР и КНДР в Россию, Народонаселение, о 3 (45).

Занребнов, Е. (2007), Экономическая организация китайской миграции на Российский Дальний Восток после распада СССР, Прогнозис, №1 (9).

Ланин, А. (2009), Китайские мигранты в России, Москва: Восточная книга.

Ларин, В. (2001), Посланцы Поднебесной на Дальнем Востоке: ответ алармистам, Диаспоры, №2-3.

Ларин, В. (2006), В тени проснувшегося дракона, Владивосток: Дальнаука.

Alexseev, Mikhail (2006), Immigration Phobia and the Security Dilemma, NY: Cambridge University Press.

Ang, Ien (2006), Undoing Diaspora: Qestioning Global Chineseness in the Era of Globalization, Hong Liu ed., Conceptualizing and Historicizing Chinese International Migration, London: Routledge.

Benton, Gregor (2007), Chinese Migrants and Internationalism: Forgotten Histories, 1917-1945, NY: Routledge. Boyko, Vladimir (2001), Chinese Communities in Western Siberia in the 1920s-1930s, Inner Asia, Vol. 3, Issue 1.

Brubaker, Rogers (2002), Ethnicity without Groups, European Journal of Sociology, Vol. 43, No. 2.

Brubaker, Rogers (2005), The 'diaspora' diaspora, Ethnic and Racial Studies, Vol. 28, No. 1 (臼杵陽監修 (2009) 『ディアスポラから世界を読む: 離散を架橋するため』明石書店, 所収)。

Cohen, Robin (1997), Global Diasporas: An Introduction, Seatle: University of Washington Press（コーエン, ロビン (2001)『グローバル・ディアスポラ』明石書店)。

Cohen, Robin (2008), Global Diasporas: An Introduction (Second Edition), NY: Routledge.

Esman, Milton (2009), Diaspora in the Contemporary World, Cambridge: Polity Press.

Goncharov, Sergei (2003), The Chinese in Russia: Who are they?, Far Eastern Affairs, No. 9.

Maslov, Alexei (1998), Russia, Lynn Pan ed., The Encyclopedia of the Chinese Overseas, Chinese Heritage Center.

Pal, Nyiri (2007), Chinese in Eastern Europe and Russia: a Middleman minority in a transnational era, NY: Routledge.

Pan, Lynn (ed.) (1998), The Encyclopedia of the Chinese Overseas, Chinese Heritage Center.

Repnikova, Maria and Harley Balzer (2009), Chinese Migration to Russia: Missed opportunities, Eurasian Migration papers No. 3, Washington, D.C.: Woodrow Wilson International Center for Scholar.

Skeldon, R. (2003), The Chinese Diaspora or the Migration of Chinese Peoples?, Laurence Ma and Carolyn Cartier eds., The Chinese Diaspora: Space, Place, Mobility, and Identity, Lanham: Rowman \& Littlefield.

Toninato, Paola (2009), The Making of Gypsy Diasporas, Translocations: Migration, and Social Change, No. 5, Issue 1.

（付記）本研究は, 平成 25 年度京都大学経済研究所プロジェクト研究, 科学研究費補助金基盤 研究（A）「東北アジアに打ける辺境地域社会再編と共生様態に関する歴史的・現在的 研究」（課題番号：23251003）の研究成果の一部である。本研究にあたっては, 長縄宣 博准教授 (北海道大学) からは本課題に取り組むきっかけを頂き, 渋谷由里准教授（富 山大学）からは貴重なご教示を頂いた。記して，感謝したい。 